\title{
INTERACTION OF DZR1, OPAQUE-2 AND NORMAL ENDOSPERM MAIZE INBRED LINES FOR GRAIN YIELD AND PROTEIN QUALITY
}

\author{
Sekip ERDAL ${ }^{1 *}$, Ahmet OZTURK ${ }^{1}$, Rahime CENGIZ ${ }^{2}$, Mehmet PAMUKCU ${ }^{1}$, Cuneyt DINCER ${ }^{3}$, Bulent \\ CENGIZ ${ }^{4}$ \\ ${ }^{1}$ Western Mediterranean Agricultural Research Institute, Antalya, TURKEY \\ ${ }^{2}$ Sakarya University of Applied Sciences, Faculty of Agriculture, Department of Field Crops, Sakarya, \\ TURKEY \\ ${ }^{3}$ Akdeniz University, Finike Vocational School, Antalya, TURKEY \\ ${ }^{4}$ Maize Research Institute, Sakarya, TURKEY \\ *Corresponding author: sekip65@yahoo.com
}

Received: 19.08.2020

\begin{abstract}
The objectives of this study were to (i) investigate genetic relationships among high lysine (HK) (opaque-2), high methionine (HM) (dzrl) and high yielding maize inbred lines (ii) to evaluate grain yield and protein quality of hybrids produced from these germplasm groups. Fifty-six hybrids generated from an $8 \times 8$ full diallel mating design were tested at two locations in Turkey in 2017 and 2018. Significant reciprocal effects for lysine, methionine, lysine quality index and methionine quality index revealed that parent effects may not be ignored in breeding for these traits. Lower grain yield among crosses produced from non-normal endosperm suggested that for high yield and improved amino acid concentration at least one parent of HK or HM should be used in hybrid combinations. HM $\times$ HM hybrids were not only good for high methionine, but also high lysine and protein. Several of the experimental hybrids in this study outperformed the commercial checks in terms of lysine and methionine yield. M2 $\times$ S1 hybrid had $27 \%$ more lysine $\left(58.6 \mathrm{~kg} \mathrm{ha}^{-1}\right)$ and $26 \%$ more methionine (42.5 $\left.\mathrm{kg} \mathrm{ha}^{-1}\right)$ yield than commercial high yielding normal hybrids. This study revealed that HK and HM germplasm can be combined with adapted high yield maize inbred lines to develop high yielding, high methionine and high lysine hybrids.
\end{abstract}

Keywords: Combining ability, diallel analysis, hybrid, lysine, methionine

\section{INTRODUCTION}

Maize protein is inadequate in some essential amino acids. Lysine and methionine are not sufficient to meet the nutritional requirements of monogastric animals, including humans (Schutte and Jong, 1999; Ravindran, 2012). Lysine and methionine are the two most important amino acids in maize-soybean poultry feed rations because costly supplementation is required to meet the recommended levels (Scott et al., 2008). Studies show that increasing methionine levels significantly increased egg production and egg weight of laying hens (Harms et al., 1998; Saki et al., 2012). In feeding trials, chickens and pigs fed high lysine maize had a higher body weight than those fed normal maize hybrids (Krivanek et al., 2007).

High lysine maize called QPM (Quality Protein Maize) contains high levels of lysine and tryptophan, the protein level is similar to normal maize. In these genotypes, amino acid balance is under the control of a recessive gene called opaque-2 (o2) which is a natural mutation (Mertz et al., 1964). Modifier/enhancer genes of the 020202 endosperm confer higher lysine in a phenotypically desirable kernel type (Vasal et al., 1993: Krivanek et al., 2007).

In a study by Phillips and McClure (1985), several lines with elevated methionine levels were identified including a line from the Iowa Stiff-Stalk Synthetic population designated BSSS53. The $10-\mathrm{kDa}$ delta zein (dzs10) is elevated in this line, causing the high methionine concentration reported by Kirihara et al. (1988). Later it was understood that dzs10 transcripts are regulated by a gene called delta zein regulator1 $(d z r l)$. Olsen et al. (2003) successfully released high methionine versions of the public inbred lines A632, B73 and Mo17 containing $d z r l$.

A study carried out by Scott et al. (2004) revealed that methionine is reduced in 0202 maize germplasm. Compositional analysis of a set of QPM hybrids showed that QPM hybrids had lower methionine levels than even 
normal maize varieties (Mbuya et al., 2011). These observations suggest that use of the opaque-2 gene in maize in poultry feed might increase the methionine supplementation requirement. Huffman et al. (2016) used a diallel study to investigate interaction of genetic mechanisms between floury-2 and $d z r l$. Interaction among opaque-2 which is the most widely used lysine modification mutation, and $d z r l$ may help in breeding for these traits. The objectives of this study are (i) to investigate genetic relationships among $d z r l$ (high methionine), opaque-2 (high lysine, QPM) and high yielding maize inbred lines based on Griffing's diallel analysis (ii) to determine grain yield and amino acid levels of the hybrids obtained from an $8 \times 8$ full diallel mating design using these three germplasm groups.

\section{MATERIALS AND METHODS}

\section{Germplasm}

The maize inbred lines used in the study are listed in Table 1. The lines $\mathrm{K} 1$ and $\mathrm{K} 2$ are rich in lysine (QPM) due to the opaque-2 mutation (Betran et al., 2003a; Betran et al., 2003b). The lines M1, M2 and M3 are high methionine versions of A632, B73 and Mo17, respectively, and they reportedly contain $12.5 \%, 25 \%$ and $50 \%$ more methionine than their wild-type counterparts (Philips et al., 2008). The line A1 is an elite line developped by Bati Akdeniz Agricultural Research Institute with high yield and drought tolerance (Erdal, 2019). The lines $S 1$ and S2 are high yielding commercial maize lines released by the Maize Research Institute of Turkey. Two widely grown high yielding normal endosperm commercial hybrids, P31G98 and DKC6589, were included in the study as checks. Crosses were done to make a complete (including reciprocals) eight by eight diallel mating design in 2016.

Table 1. Maize inbred lines used in the eight by eight diallel design

\begin{tabular}{|c|c|c|c|c|}
\hline Line & Name & Specific trait & $\begin{array}{l}\text { Heterotic } \\
\text { group }\end{array}$ & Source \\
\hline $\mathrm{K} 1$ & $\mathrm{~T} \times 802$ & $\begin{array}{l}\text { High lysine (opague-2, } \\
\text { QPM) }\end{array}$ & $\begin{array}{l}\text { Tropical / } \\
\text { subtropical }\end{array}$ & Texas A\&M University \\
\hline $\mathrm{K} 2$ & $\mathrm{~T} \times 807$ & $\begin{array}{l}\text { High lysine (opague-2, } \\
\text { QPM) }\end{array}$ & $\begin{array}{l}\text { Tropical / } \\
\text { subtropical }\end{array}$ & Texas A\&M University \\
\hline M1 & $\begin{array}{l}58609 \text { A632 } \\
\text { (Meth) }\end{array}$ & $\begin{array}{l}\text { High methionine } \\
(d z r l)\end{array}$ & Stiff-Stalk & $\begin{array}{l}\text { Minnesota Agricultural } \\
\text { Experiment Station }\end{array}$ \\
\hline M2 & $\begin{array}{l}58615 \text { B73 } \\
\text { (Meth) }\end{array}$ & $\begin{array}{l}\text { High methionine } \\
(d z r l)\end{array}$ & Stiff-Stalk & $\begin{array}{l}\text { Minnesota Agricultural } \\
\text { Experiment Station }\end{array}$ \\
\hline M3 & $\begin{array}{l}58803 \text { Mo17 } \\
\text { (Meth) }\end{array}$ & $\begin{array}{l}\text { High methionine } \\
(d z r l)\end{array}$ & Lancaster & $\begin{array}{l}\text { Minnesota Agricultural } \\
\text { Experiment Station }\end{array}$ \\
\hline A1 & Ant-24702 & $\begin{array}{l}\text { High yielding/elite/ drought } \\
\text { tolerant }\end{array}$ & Lancaster & $\begin{array}{l}\text { Bati Akdeniz Agricultural } \\
\text { Research Institute }\end{array}$ \\
\hline S1 & ADK-451 & $\begin{array}{l}\text { High yielding /Commercial } \\
\text { line }\end{array}$ & Leaming & Maize Research Institute of Turkey \\
\hline $\mathrm{S} 2$ & ADK-455 & $\begin{array}{l}\text { High yielding /Commercial } \\
\text { line }\end{array}$ & Stiff-Stalk & Maize Research Institute of Turkey \\
\hline
\end{tabular}

\section{Experimental design}

All 56 hybrids and the two check varieties were evaluated as entries in a randomized complete block design with three replications. The locations Antalya (southern Turkey) and Sakarya (northern Turkey) were used in 2017 and 2018 to produce four testing environments. Antalya $\left(36^{0} 52^{\prime} \mathrm{N} 30^{\circ} 45^{\prime} \mathrm{E}\right)$ is a typical mediterranean province where the climate is warm in summer and the winter months are more rainer than the summer months. Sakarya $\left(40^{\circ} 48^{\prime} \mathrm{N} 30^{\circ} 25^{\prime} \mathrm{E}\right)$ province has a rainy and humid weather and a temperate climate. Winters are rainy and warm, and summers are hot. Experimental plots consisted of 2 rows, $5 \mathrm{~m}$ long and 0.70 $\mathrm{m}$ between rows. In order to eliminate the pollen effect on kernel protein quality, 5 plants in the first row of each plot were self pollinated and the resulting grain was bulked for amino acid analysis. Sowing were done in April (Antalya) and May (Sakarya) in both years. Before sowing, $600 \mathrm{~kg}$ $\mathrm{ha}^{-1}$ of composite $15-15-15$ fertilizer was applied to the experiments area to provide $90 \mathrm{~kg} \mathrm{ha}^{-1}$ for each $\mathrm{N}, \mathrm{P}$ and $\mathrm{K}$ elements. Later, $152 \mathrm{~kg} \mathrm{ha}^{-1}$ of $\mathrm{N}$ dose using $46 \%$ urea fertilizer, was given to the soil in a few different times (TTSMM, 2018). To control weeds in the experiments, $225 \mathrm{~g} / \mathrm{L}$ Isoxaflutole $+90 \mathrm{~g} / \mathrm{L}$ Thiencarbazone-methyl + $150 \mathrm{~g} / \mathrm{L}$ Cyprosulfamide active ingredient herbicide was applied after plant emergence. Experiments were regularly irrigated to avoid water stress till harvest.

Grain yield ( $\mathrm{t} \mathrm{ha}^{-1}$ ) was determined from the second row of each plot and adjusted to $15 \%$ grain moisture content at harvest. Protein concentration was determined by the Dumas classical method (AOAC International, 2002). Liquid Chromatography Triple Quadrupole Mass Spectrometry (LC-MS/MS) was used for quantifying methionine and lysine. Before analysis, maize samples 
were hydrolized using the method of Chan and Matanjun (2017) which was modified according to Faountoukakis and Lahm (1998). Amount of $0.2 \mathrm{~g}$ of the sample was homogenized and weighed into a solution of $10 \mathrm{~mL}$ of $6 \mathrm{~N}$ $\mathrm{HCl}$ (containing $0.02 \%$ of phenol). The mixture was mixed by vortexing in a tightly sealed test tube for $5 \mathrm{~min}$ and then stored in an oven at $110{ }^{\circ} \mathrm{C}$ for $24 \mathrm{~h}$ to complete the hydrolysis. Following cooling to room temperature, the mixture was filtered through a $0.45 \mu \mathrm{m}$ PTFE membrane and then injected into the LC-MS/MS device. Total lysine and methionine values were calculated as concentration (g / $100 \mathrm{~g}$, dry matter). Protein quality indexes were calculated for both lysine and methionine by dividing the amino acid concentration by the total protein concentration.

\section{Statistical analysis}

The field plot data was subjected to analysis of variance (ANOVA). Least significant difference (LSD) test (Steel and Torrie, 1980) was used when the difference between means were statistically significant. Analysis of Genetic Designs, AGD-R, a statistical software programme which was developed by Rodriguez et al. (2015) was used to analyze the diallel data using Griffing (1956) method III model I (fixed). In this analysis, variance was partitioned into the components listed in Table 2, which were all considered to be fixed effects in a linear model. The model effects for general combining ability (GCA), specific combining ability (SCA), reciprocal, maternal, non-maternal and their interactions were tested for significance using an F-test based on the estimated sums of squares generated by the linear model. In addition, variance components such as GCA / SCA ratio, phenotypic variance, narrow and broad sense heritability were estimated using AGD-R (Rodriguez et al., 2015). Comparisons between the high lysine (HK), high methionine (HM) and high yield (HY) groups were made using specific contrasts and trait correlations were determined using Pearson correlation coefficients.

Table 2. Analysis of variance (ANOVA) and variance components for investigated traits

\begin{tabular}{|c|c|c|c|c|c|c|c|}
\hline & & $\begin{array}{c}\text { Grain yield } \\
\left(\mathrm{t} \mathrm{ha}^{-1}\right)\end{array}$ & $\begin{array}{l}\text { Protein } \\
(\%)\end{array}$ & $\begin{array}{r}\text { Lysine } \\
(\mathrm{g} / 100 \mathrm{~g})\end{array}$ & $\begin{array}{l}\text { Methionine } \\
(\mathrm{g} / 100 \mathrm{~g})\end{array}$ & $\begin{array}{l}\text { KQI } \\
(\%) \\
\end{array}$ & $\begin{array}{l}\text { MQI } \\
(\%)\end{array}$ \\
\hline Source of variation & DF & \multicolumn{6}{|c|}{ Mean square error } \\
\hline Environment (E) & 3 & $11082806 * *$ & $13.80 * *$ & $0.022182 * *$ & $0.00976 * *$ & $4.99 * *$ & $5.99 * *$ \\
\hline Replication & 8 & $80162.84 * *$ & $1.53 * *$ & $0.000444 *$ & $0.001928 * *$ & $0.04 *$ & $0.84 * *$ \\
\hline Genotype (G) & 55 & $257512.8 * *$ & $6.05 * *$ & $0.008789 * *$ & $0.004297 * *$ & $0.66 * *$ & $17.69 * *$ \\
\hline $\mathrm{GCA}$ & 7 & $1492202 * *$ & $37.93 * *$ & $0.027756 * *$ & $0.018349 * *$ & $0.80 * *$ & $6.44 *$ \\
\hline SCA & 20 & $99774.21 *$ & $1.88 *$ & $0.005936 * *$ & $0.001595 *$ & $0.43^{\mathrm{ns}}$ & $3.33^{\mathrm{ns}}$ \\
\hline Reciprocal (R) & 28 & $61511^{\mathrm{ns}}$ & $1.06^{\mathrm{ns}}$ & $0.006085 * *$ & $0.002715 * *$ & $0.79 * *$ & $7.92 * *$ \\
\hline Maternal (M) & 7 & $103063.3 *$ & $1.16^{\mathrm{ns}}$ & $0.014525 * *$ & $0.006551 *$ & $1.76 * *$ & $3.36^{\mathrm{ns}}$ \\
\hline Non-maternal (NM) & 21 & $47660.22 \mathrm{~ns}$ & $1.03 \mathrm{~ns}$ & $0.003272 * *$ & $0.001436 * *$ & $0.46 * *$ & $4.56 * *$ \\
\hline $\mathrm{E} \times \mathrm{G}$ & 165 & $60459.03 * *$ & $1.24 * *$ & $0.001425 * *$ & $0.001213 * *$ & $0.19 * *$ & $23.17 * *$ \\
\hline $\mathrm{E} \times \mathrm{GCA}$ & 21 & $119838.6 * *$ & $2.92 * *$ & $0.000701 \mathrm{~ns}$ & $0.003915 * *$ & $0.08 \mathrm{~ns}$ & $7.45 * *$ \\
\hline $\mathrm{E} \times \mathrm{SCA}$ & 60 & $47310.73 * *$ & $1.07 * *$ & $0.001926 * *$ & $0.000881 * *$ & $0.26 * *$ & $7.09 * *$ \\
\hline $\mathrm{E} \times \mathrm{R}$ & 84 & $55005.8 * *$ & $0.94 * *$ & $0.001248 * *$ & $0.000775 * *$ & $0.17 * *$ & $8.62 * *$ \\
\hline $\mathrm{E} \times \mathrm{M}$ & 21 & $47423.91 \mathrm{~ns}$ & $0.94 \mathrm{~ns}$ & $0.002534 * *$ & $0.002004 * *$ & $0.25 *$ & $4.74 * *$ \\
\hline $\mathrm{E} \times \mathrm{NM}$ & 63 & $57533.09 * *$ & $0.94 * *$ & $0.00082 * *$ & $0.000366 * *$ & $0.14 * *$ & $3.88 * *$ \\
\hline Residual & 440 & 30509.21 & 0.29 & 0.000156 & 0.000147 & 0.01 & 3.17 \\
\hline \multicolumn{8}{|c|}{ Magnitude of the variance components } \\
\hline GCA & & 40602.57 & 1.05 & 0.00115 & 0.000758 & 0.03 & 0.048 \\
\hline SCA & & 11544.17 & 0.27 & 0.001445 & 0.000362 & 0.10 & 0.038 \\
\hline M & & 1154.23 & 0.01 & 0.000352 & 0.00016 & 0.04 & 0.008 \\
\hline NM & & 2858.50 & 0.12 & 0.000779 & 0.000322 & 0.11 & 0.051 \\
\hline GCA/SCA & & 3.52 & 3.94 & 0.80 & 2.09 & 0.32 & 0.99 \\
\hline Phenotypic Variance & & 128425.50 & 2.77 & 0.005384 & 0.002668 & 0.38 & 0.195 \\
\hline Narrow Heritability & & 0.63 & 0.75 & 0.43 & 0.57 & 0.17 & 0.39 \\
\hline Broad Heritability & & 0.72 & 0.85 & 0.70 & 0.70 & 0.45 & 0.58 \\
\hline
\end{tabular}

* Significant at the 0.05 probability level, ${ }^{*} *$ Significant at the 0.01 probability level, ${ }^{\mathrm{ns}}$ not significant

\section{RESULTS AND DISCUSSION}

\section{Analysis of variance and genetic components}

Results of combined analysis of variance (ANOVA) and genetic components for measured traits are presented in Table 2. Since the differences among genotypes were significant, diallel analysis was performed. General combining ability (GCA) effects are considered to be governed by additive gene action and were found to be significant for all traits. Significant specific combining abilitiy (SCA) effects were detected in grain yield, protein, lysine, and methionine while non-significiant effects were determined in lysine quality index (KQI) and methionine quality index (MQI). Significiant reciprocal (R) effects were identified for lysine, methionine, KQI and MQI traits, showing that the direction of the cross impacted the cross performance. Therefore it would be beneficial to evaluate crosses and their reciprocals in test experiments. Significant maternal effects were found for grain yield, lysine, methionine and KQI. Significant environment $(\mathrm{E}) \times \mathrm{GCA}, \mathrm{E} \times \mathrm{SCA}$ and $\mathrm{E} \times \mathrm{R}$ interactions 
showed the importance of environmental effects on these genetic components (Table 2).

GCA/SCA ratios may give some information about the trait heritability, because the additive effects determine GCA are more heritable than the non-additive effects that determine SCA. Non-additive gene effects are more prevalent in lysine, KQI and MQI traits (GCA/SCA <1). The highest narrow sense heritability value $(0.75)$ was for protein while the lowest value was obtained for KQI (0.17). Both narrow and broad sense heritability were lower for lysine and methionine when compared to grain yield and protein (Table 2).

Although grain yield is reportedly influenced by nonadditive genetic variance (Nas et al., 2000) in maize, Duraes et al. (2002) Hallauer and Carena (2009) and Erdal et al. (2015) reported that the variance of additive gene effects was more important for grain yield. Heritability varies greatly among studies and is dependent on the genotypes used in a study, the environmental conditions and many other factors. In this study, relatively high heritability is expected due to presence of large effect genes controlling the traits of interest. For example, $o 2$ has a large effect on both lysine and yield. High narrow (0.75) and broad (0.85) sense heritability values suggest protein concentration can be improved via breeding. High additive gene effects for methionine revealed by Huffman et al. (2016) are consistent with our results related to methionine heritability.

\section{Combining ability analysis}

General combining ability (GCA) effects for investigated traits are presented in Table 3. Significant and positive GCA values for yield were obtained from high yielding normal endosperm (S1 and A1) inbred lines. M1 (dzrl), K1 (opaque-2) and K2 (opaque-2) inbred lines have negative and significant effects indicating the lower yield potential of high amino acid germplasm. Grain protein concentration GCA values were statistically significant in all lines $(\mathrm{p}<0.01$ and $\mathrm{p}<0.05)$. The highest and lowest results were obtained from the M1 (0.82) and S1 (-0.65) lines, respectively. The highest positive and significant lysine GCA effect was obtained from line M1 (0.016), while the lines K2, M3, M2 followed. Negative and significant GCA for lysine was obtained in normal endosperm lines (A1, S1, S2). When methionine GCA values were examined, it was determined that the lines containing dzrl (M1, M2 and M3) have the highest positive and significant results $(\mathrm{p}<0.01)$. Therefore, we conclude that $d z r l$ lines are effective parents for creating high methionine hybrids. When lysine quality index (KQI) results were examined, positive and significant results were obtained only for K1 and K2 lines (QPM). It was determined that the S1, S2 (normal endosperm) and M2 lines were the best lines for MQI GCA effects.

Specific combining ability (SCA) effects for investigated traits are given in Table 4. The highest positive and significant SCA effects in terms of grain yield were from the combinations M1 × K1 (129.83), A1 $\times$ M3 (66.47) and M3 $\times$ K2 (64.07). In the grain protein concentration, A1 $\times$ M3 (0.46) ranked first while M1 $\times \mathrm{K} 1$ combination (0.40) was second and S2 $\times \mathrm{K} 1(0.36)$ was the third. The highest positive and significant SCA effects in terms of grain lysine concentration were from the M1 $\times$ $\mathrm{K} 1, \mathrm{~A} 1 \times \mathrm{M} 2$ and $\mathrm{S} 2 \times \mathrm{K} 1$ combinations, respectively. S1 $\times \mathrm{M} 3, \mathrm{~S} 1 \times \mathrm{K} 2$ and $\mathrm{M} 1 \times \mathrm{K} 1$ were the best combinations for methionine. A1 $\times \mathrm{M} 2$ for KQI and $\mathrm{S} 1 \times \mathrm{M} 3$ were the most successful combinations in terms of MQI.

Table 3. General combining ability effects for grain yield, protein, lysine, methionine, lysine quality index (KQI) and methionine quality index (MQI)

\begin{tabular}{ccccccc}
\hline Parents & Grain Yield & Protein & Lysine & Methionine & KQI & MQI \\
\hline K1 & $-28.80^{*}$ & $-0.42^{* *}$ & $-0.00071 \mathrm{~ns}$ & $-0.01615^{* *}$ & $0.151511^{* *}$ & $-0.04975^{* *}$ \\
K2 & $-34.22^{*}$ & $0.11^{*}$ & $0.014494^{* *}$ & $-0.01334^{* *}$ & $0.078722^{* *}$ & $-0.16689^{* *}$ \\
M1 & $-191.15^{* *}$ & $0.82^{* *}$ & $0.015601 * *$ & $0.015951^{* *}$ & $-0.14622^{* *}$ & $-0.05706^{* *}$ \\
M2 & $-10.78 \mathrm{~ns}$ & $0.51^{* *}$ & $0.013629 * *$ & $0.021875^{* *}$ & $-0.05899^{* *}$ & $0.073152^{* *}$ \\
M3 & $1.23 \mathrm{~ns}$ & $0.27 * *$ & $0.013807 * *$ & $0.006157^{* *}$ & $0.045614^{* *}$ & $-0.00111 \mathrm{~ns}$ \\
A1 & $98.68^{* *}$ & $-0.18^{* *}$ & $-0.01036^{* *}$ & $-0.00867 * *$ & $-0.0261^{*}$ & $-0.02949 *$ \\
S1 & $155.06^{* *}$ & $-0.65^{* *}$ & $-0.02509^{* *}$ & $-0.00716^{* *}$ & $-0.00673 \mathrm{~ns}$ & $0.099292^{* *}$ \\
S2 & $9.98 \mathrm{~ns}$ & $-0.46^{* *}$ & $-0.02138^{* *}$ & $0.001339 \mathrm{~ns}$ & $-0.03782^{* *}$ & $0.131847^{* *}$ \\
\hline
\end{tabular}

* Significant at the 0.05 probability level, $* *$ Significant at the 0.01 probability level, ${ }^{\mathrm{ns}}$ not significant

It was observed that M1, M2, M3 and K2 inbred lines can be used for high protein concentration breeding studies. Methionine gerpmlasm did not only have good GCA effects for methionine but also for high lysine concentration. Higher KQI GCA effects of opaque-2 lines are consistent with previous studies that have shown QPM hybrids have high protein quality in terms of lysine. The International Maize and Wheat Improvement Center (CIMMYT) is one of the leading institutions to develop QPM (high tryptophan and lysine) lines and hybrids (Vivek et al., 2008). CIMMYT breeders generally used the KQI trait when developing QPM varieties. Since QPM lines used in our study were developed from CIMMYT populations, it was not suprising that these lines had high GCA values in terms of KQI. When the methionine quality index (MQI) GCA values were examined, it was observed that the first two ranks were from the S1 and S2 lines, which were high yielding and normal endosperm lines. These lines did not produce very good results in terms of methionine concentration, but they combined very well with any high methionine (M1, M2 and M3) line, in other words, they served as complementary lines. 
Therefore, these two lines can be used for their complementary effects.

Table 4. Specific combining ability effects for grain yield, protein, lysine, methionine, lysine quality index (KQI) and methionine quality index (MQI)

\begin{tabular}{|c|c|c|c|c|c|c|}
\hline Hybrid & Grain yield & Protein & Lysine & Methionine & KQI & MQI \\
\hline $\mathrm{K} 2 \times \mathrm{K} 1$ & $-93.34 * *$ & $-0.09^{\text {ns }}$ & $0.013146 * *$ & $-0.0017^{\mathrm{ns}}$ & $0.157093 * *$ & $-0.01073^{\mathrm{ns}}$ \\
\hline $\mathrm{M} 1 \times \mathrm{K} 1$ & $129.83 * *$ & $0.40 * *$ & $0.031946 * *$ & $0.010703 * *$ & $0.152002 * *$ & $0.014326^{\mathrm{ns}}$ \\
\hline $\mathrm{M} 1 \times \mathrm{K} 2$ & $8.28^{\mathrm{ns}}$ & $-0.27 * *$ & $0.005379 *$ & $0.000644^{\mathrm{ns}}$ & $0.112161 * *$ & $0.06665^{*}$ \\
\hline $\mathrm{M} 2 \times \mathrm{K} 1$ & $52.19^{\text {ns }}$ & $-0.01^{\mathrm{ns}}$ & $-0.0324 * *$ & $-0.0162 * *$ & $-0.28243 * *$ & $-0.12609 * *$ \\
\hline $\mathrm{M} 2 \times \mathrm{K} 2$ & $-27.59^{\mathrm{ns}}$ & $0.26 * *$ & $-0.02323 * *$ & $-0.00736 * *$ & $-0.29872 * *$ & $-0.12222 * *$ \\
\hline $\mathrm{M} 2 \times \mathrm{M} 1$ & $-114.95 * *$ & $-0.01^{\mathrm{ns}}$ & $-0.00248 n s$ & $0.000882^{\mathrm{ns}}$ & $0.007736^{\mathrm{ns}}$ & $0.015117^{\mathrm{ns}}$ \\
\hline $\mathrm{M} 3 \times \mathrm{K} 1$ & $-67.68 *$ & $-0.51 * *$ & $-0.01063 * *$ & $0.002476^{\mathrm{ns}}$ & $0.07488 * *$ & $0.135216^{* *}$ \\
\hline $\mathrm{M} 3 \times \mathrm{K} 2$ & $64.07 *$ & $0.16^{\mathrm{ns}}$ & $-0.00863 * *$ & $-0.01608 * *$ & $-0.13679 * *$ & $-0.17493 * *$ \\
\hline $\mathrm{M} 3 \times \mathrm{M} 1$ & $35.29^{\mathrm{ns}}$ & $-0.20 *$ & $-0.0159 * *$ & $-0.00847 * *$ & $-0.08127 * *$ & $-0.03794^{\mathrm{ns}}$ \\
\hline $\mathrm{M} 3 \times \mathrm{M} 2$ & $-18.36^{\mathrm{ns}}$ & $0.12^{\mathrm{ns}}$ & $0.015736 * *$ & $0.001421^{\mathrm{ns}}$ & $0.076402^{* *}$ & $-0.03647^{\mathrm{ns}}$ \\
\hline $\mathrm{A} 1 \times \mathrm{K} 1$ & $-37.31^{\mathrm{ns}}$ & $-0.28 * *$ & $-0.02839 * *$ & $-0.00246^{\mathrm{ns}}$ & $-0.17473 * *$ & $0.046471^{\mathrm{ns}}$ \\
\hline $\mathrm{A} 1 \times \mathrm{K} 2$ & $9.29^{\mathrm{ns}}$ & $-0.06^{\mathrm{ns}}$ & $-0.00663^{*}$ & $0.009444 * *$ & $-0.04583^{\mathrm{ns}}$ & $0.098266^{* *}$ \\
\hline $\mathrm{A} 1 \times \mathrm{M} 1$ & $-78.34 *$ & $0.31 * *$ & $0.007127 * *$ & $0.006346^{*}$ & $-0.03874^{\mathrm{ns}}$ & $-0.01812^{\mathrm{ns}}$ \\
\hline $\mathrm{A} 1 \times \mathrm{M} 2$ & $43.98^{\mathrm{ns}}$ & $-0.08^{\mathrm{ns}}$ & $0.031017 * *$ & $0.006194 *$ & $0.303533^{* *}$ & $0.063593^{*}$ \\
\hline $\mathrm{A} 1 \times \mathrm{M} 3$ & $66.47 *$ & $0.46 * *$ & $0.018261 * *$ & $0.003095^{\mathrm{ns}}$ & $0.027155^{\mathrm{ns}}$ & $-0.06987 * *$ \\
\hline $\mathrm{S} 1 \times \mathrm{K} 1$ & $38.21^{\mathrm{ns}}$ & $0.13^{\mathrm{ns}}$ & $0.003883^{\mathrm{ns}}$ & $-0.0019^{\mathrm{ns}}$ & $-0.04924^{\mathrm{ns}}$ & $-0.08504 * *$ \\
\hline $\mathrm{S} 1 \times \mathrm{K} 2$ & $26.83^{\text {ns }}$ & $0.21 *$ & $0.011974 * *$ & $0.011587 * *$ & $0.102396^{* *}$ & $0.088927 * *$ \\
\hline $\mathrm{S} 1 \times \mathrm{M} 1$ & $-42.09^{n s}$ & $-0.28 * *$ & $-0.00564 *$ & $-0.01064 * *$ & $0.046177^{\mathrm{ns}}$ & $-0.03273^{\mathrm{ns}}$ \\
\hline $\mathrm{S} 1 \times \mathrm{M} 2$ & $62.04 *$ & $-0.13^{\mathrm{ns}}$ & $0.013501 * *$ & $0.009233^{* *}$ & $0.161581 * *$ & $0.117808^{* *}$ \\
\hline $\mathrm{S} 1 \times \mathrm{M} 3$ & $-51.93^{\mathrm{ns}}$ & $-0.10^{\mathrm{ns}}$ & $-0.00621 *$ & $0.013102 * *$ & $-0.01968^{\mathrm{ns}}$ & $0.154996^{* *}$ \\
\hline $\mathrm{S} 1 \times \mathrm{A} 1$ & $-4.91^{\mathrm{ns}}$ & $-0.01^{\mathrm{ns}}$ & $-0.01183 * *$ & $-0.01033^{* *}$ & $-0.09369 * *$ & $-0.08724 * *$ \\
\hline $\mathrm{S} 2 \times \mathrm{K} 1$ & $-21.91^{\mathrm{ns}}$ & $0.36 * *$ & $0.02245^{* *}$ & $0.009082 * *$ & $0.122438 * *$ & $0.025842^{\mathrm{ns}}$ \\
\hline $\mathrm{S} 2 \times \mathrm{K} 2$ & $12.45^{\mathrm{ns}}$ & $-0.20 *$ & $0.007984 * *$ & $0.003458^{\mathrm{ns}}$ & $0.109682 * *$ & $0.054029 *$ \\
\hline $\mathrm{S} 2 \times \mathrm{M} 1$ & $61.97 *$ & $0.05^{\mathrm{ns}}$ & $-0.02043 * *$ & $0.000529^{\mathrm{ns}}$ & $-0.19807 * *$ & $-0.00731^{\mathrm{ns}}$ \\
\hline $\mathrm{S} 2 \times \mathrm{M} 2$ & $2.68^{\mathrm{ns}}$ & $-0.15^{\mathrm{ns}}$ & $-0.00215 n s$ & $0.00583 *$ & $0.0319 \mathrm{~ns}$ & $0.088261 * *$ \\
\hline $\mathrm{S} 2 \times \mathrm{M} 3$ & $-27.86^{\mathrm{ns}}$ & $0.08^{\mathrm{ns}}$ & $0.007378^{* *}$ & $0.00445^{\mathrm{ns}}$ & $0.059298 *$ & $0.028989^{\mathrm{ns}}$ \\
\hline $\mathrm{S} 2 \times \mathrm{A} 1$ & $0.82^{\mathrm{ns}}$ & $-0.33 * *$ & $-0.00955^{* *}$ & $-0.01229 * *$ & $0.022295^{\mathrm{ns}}$ & $-0.03309^{\mathrm{ns}}$ \\
\hline $\mathrm{S} 2 \times \mathrm{S} 1$ & $-28.15^{\mathrm{ns}}$ & $0.19 *$ & $-0.00568 *$ & $-0.01106 * *$ & $-0.14754 * *$ & $-0.15672 * *$ \\
\hline
\end{tabular}

* Significant at the 0.05 probability level, ${ }^{* *}$ Significant at the 0.01 probability level, ${ }^{\mathrm{ns}}$ not significant

\section{Contrasts between germplasm groups}

In order to better understand the the effects of the major genes $d z r l$ and opaque-2 in the germplasm used in this study, we compared the performance of the three germplasm groups: HY (no major genes), HM $(d z r l)$ and HK (opaque-2) (Table 5). The high yielding lines (HY) gave the highest grain yield values in both the male and female group comparisons. On the other hand, the high lysine (HK) and high methionine (HM) groups were found to have similar grain yields. HM lines were found to have the highest protein concentration in both female and male, while HY lines were found to have low protein values (Table 5).

When the interactions were considered, it was observed that combinations of $\mathrm{HM} \times \mathrm{HK}(0.367 \mathrm{~g} / 100 \mathrm{~g})$ and $\mathrm{HM} \times \mathrm{HM}(0.362 \mathrm{~g} / 100 \mathrm{~g})$ gave the highest lysine results, while the lowest result was produced in the HY $\times$ HY combination $(0.287 \mathrm{~g} / 100 \mathrm{~g})$ (Table 5).

The highest methionine concentrations were obtained from the HM group and the highest lysine concentrations were obtained from the HK group regardless of which parent contributed the germplasm group. The HK group had lowest methionine levels regardless of which parent contributed this group. Interstingly, the $\mathrm{HM} \times \mathrm{HM}$ combination was in the top significance group for both lysine and methionine concentrations, while the $\mathrm{HK} \times \mathrm{HK}$ combination was in the top significance group for lysine concentration, but in the bottom significance group for methionine.

The contrast between the three germplasm groups HY, $\mathrm{HK}$ and HM showed that lowest yield results were obtained from hybrids of $\mathrm{HK} \times \mathrm{HK}$ and $\mathrm{HM} \times \mathrm{HM}$ lines. This finding shows that quality protein (both methionine and lysine) germplasm that we used in this study have low yield potential. Using HM and HK germplasm classes in combination with HY groups could be an option. However, this is rarely done in protein quality breeding programs. It is therefore of interest to consider our results in light of what is known about the gene action of these major genes. Although lysine levels are influenced by the opaque-2 gene, the level of lysine in genotypes varies due to modifier / enhancer loci in QPM genetic material. This supports the suggestion that lysine levels should be measured throughout the course of breeding programs (Vivek et al., 2008). Our data suggests that $d z r l$ may be a modifier of lysine levels when used as a female parent. While HK $\times$ HK hybrids had high lysine levels, they had low methionine levels, consistent with previous reports that opaque-2 hybrids have low methionine levels Scott et al. (2004). 
Table 5. Effect of parents on grain yield $\left(\mathrm{t} \mathrm{ha}^{-1}\right)$, protein $(\%)$, lysine $(\mathrm{g} / 100 \mathrm{~g})$ and methionine (\%) concentration

\begin{tabular}{|c|c|c|c|c|}
\hline & \multicolumn{4}{|c|}{ Female group } \\
\hline & Yield** & Protein** & Lysine** & Methionine** \\
\hline HK & $11.69 \mathrm{~b}$ & $10.26 \mathrm{~b}$ & $0.336 \mathrm{~b}$ & $0.212 \mathrm{c}$ \\
\hline HM & $11.99 \mathrm{~b}$ & $10.91 \mathrm{a}$ & $0.359 \mathrm{a}$ & $0.253 \mathrm{a}$ \\
\hline \multirow[t]{3}{*}{ HY } & $13.35 \mathrm{a}$ & $9.96 \mathrm{c}$ & $0.313 \mathrm{c}$ & $0.223 \mathrm{~b}$ \\
\hline & \multicolumn{4}{|c|}{ Male group } \\
\hline & Yield** & Protein** & Lysine** & Methionine $* *$ \\
\hline HK & $12.17 \mathrm{~b}$ & $10.20 \mathrm{~b}$ & $0.353 \mathrm{a}$ & $0.221 \mathrm{c}$ \\
\hline $\mathrm{HM}$ & $11.57 \mathrm{~b}$ & $10.95 \mathrm{a}$ & $0.338 \mathrm{~b}$ & $0.239 \mathrm{a}$ \\
\hline \multirow[t]{3}{*}{ HY } & $13.30 \mathrm{a}$ & $9.98 \mathrm{c}$ & $0.317 \mathrm{c}$ & $0.229 \mathrm{~b}$ \\
\hline & \multicolumn{4}{|c|}{ Female by male group } \\
\hline & Yield $^{\mathrm{ns}}$ & Protein ${ }^{n s}$ & lysine* & methionine $* *$ \\
\hline $\mathrm{HK} \times \mathrm{HK}$ & 10.92 & 10.02 & $0.361 \mathrm{ab}$ & $0.202 \mathrm{~d}$ \\
\hline $\mathrm{HM} \times \mathrm{HM}$ & 10.82 & 11.45 & $0.362 \mathrm{a}$ & $0.261 \mathrm{a}$ \\
\hline $\mathrm{HY} \times \mathrm{HY}$ & 14.14 & 9.51 & $0.287 \mathrm{e}$ & $0.212 \mathrm{~cd}$ \\
\hline $\mathrm{HK} \times \mathrm{HM}$ & 11.39 & 10.81 & $0.331 \mathrm{c}$ & $0.218 \mathrm{~cd}$ \\
\hline $\mathrm{HK} \times \mathrm{HY}$ & 12.75 & 9.95 & $0.316 \mathrm{~d}$ & $0.217 \mathrm{~cd}$ \\
\hline $\mathrm{HM} \times \mathrm{HK}$ & 12.15 & 10.79 & $0.367 \mathrm{a}$ & $0.240 \mathrm{~b}$ \\
\hline $\mathrm{HM} \times \mathrm{HY}$ & 13.01 & 10.48 & $0.348 \mathrm{~b}$ & $0.257 \mathrm{a}$ \\
\hline $\mathrm{HY} \times \mathrm{HK}$ & 13.44 & 9.78 & $0.332 \mathrm{c}$ & $0.220 \mathrm{c}$ \\
\hline $\mathrm{HY} \times \mathrm{HM}$ & 12.46 & 10.6 & $0.321 \mathrm{~cd}$ & $0.237 \mathrm{~b}$ \\
\hline
\end{tabular}

* Significant at the 0.05 probability level, $* *$ Significant at the 0.01 probability level, ${ }^{\text {ns }}$ not significant

Mean grain yield, quality characteristics, lysine and methionine levels of the hybrids

Mean values of the investigated traits for all 56 diallel crosses and commercial checks across four environments are given in Table 6. Our study showed significant varation among genotypes $(\mathrm{p}<0.01)$ for grain yield and compositional traits. Grain yield ranged from 16.1 to $9.3 \mathrm{t}$ $\mathrm{ha}^{-1}$. Normal $\mathrm{x}$ normal endosperm $(\mathrm{HY} \times \mathrm{HY})$ hybrids including commercial checks had higher yield as expected. A1 $\times \mathrm{S} 1\left(16.1 \mathrm{t} \mathrm{ha}^{-1}\right)$ and M2 $\times \mathrm{S} 1\left(15.5 \mathrm{t} \mathrm{ha}^{-1}\right)$ were superior to commercial check means $\left(14.7 \mathrm{t} \mathrm{ha}^{-1}\right)$. The high grain yield of M2 $\times \mathrm{S} 1(\mathrm{HM} \times \mathrm{HY})$ showed that high grain yield can be achived in $d z r l \times$ normal endosperm crosses. On the other hand, in general lower grain yields were obtained from crosses containing high amino acid inbreds.

The mean protein values of the experimental crosses and checks were $10.4 \%$ and $9.5 \%$ respectively. The highest protein values were obtained from M2 $\times$ M1 $(12.1$ $\%), \mathrm{M} 1 \times \mathrm{K} 1(11.6 \%)$ and M1 $\times \mathrm{A} 1(11.6 \%)$ showing that $d z r l$ germplasm combined well in terms of protein concentration. Whole kernel lysine concentration varied from $0.26 \mathrm{~g} / 100 \mathrm{~g}$ dry matter $(\mathrm{S} 2 \times \mathrm{A} 1)$ to $0.40 \mathrm{~g} / 100 \mathrm{~g}$ dry matter $(\mathrm{K} 1 \times \mathrm{M} 1)$ in hybrids. The mean of the crosses $(0.33 \mathrm{~g} / 100 \mathrm{~g})$ was higher than mean of checks $(0.29$ $\mathrm{g} / 100 \mathrm{~g})$. The M2 $\times \mathrm{M} 3, \mathrm{M} 2 \times \mathrm{A} 1, \mathrm{M} 2 \times \mathrm{S} 1, \mathrm{M} 3 \times \mathrm{K} 1, \mathrm{M} 3$ $\times \mathrm{K} 2$ hybrid combinations all had $0.38 \mathrm{~g} / 100 \mathrm{~g}$ lysine showing that $d z r l$ (M2 and M3) inbred lines performed well for lysine concentration. The lowest lysine values were generally obtained from non-opaque-2 and non- $d z r l$ germplasm demonstrating that at least one parent must contain opaque-2 or $d z r l$ to get a high lysine hybrid. Scott et al. (2009) compared normal genotypes with high lysine genotypes that gave $0.290 \mathrm{~g} / 100 \mathrm{~g}$ and $0.330 \mathrm{~g} / 100 \mathrm{~g}$ lysine, respectively. The values in high-lysine-containing genotypes ranged from 0.390 to $0.510 \mathrm{~g} / 100 \mathrm{~g}$. In a study of Carena and Dong (2017), experiment averages were found to be $0.318 \mathrm{~g} / 100 \mathrm{~g}$ and $0.303 \mathrm{~g} / 100 \mathrm{~g}$ for trial 1 and 2 , respectively. Findings of our study were slightly lower than Scott et al. (2009). However, our results were consistent with Carena and Dong (2017), with relatively higher results. Different genotypes and different environments and methods were used in the studies and could explain the differences observed.

Methionine values of the hybrids ranged from 0.28 to $0.19 \mathrm{~g} / 100 \mathrm{~g}$ and the mean of crosses $(0.23 \mathrm{~g} / 100 \mathrm{~g})$ was significanlty higher than the mean of checks. M2 $\times \mathrm{S} 1$ $(0.28 \mathrm{~g} / 100 \mathrm{~g}), \mathrm{M} 1 \times \mathrm{M} 2(0.27 \mathrm{~g} / 100 \mathrm{~g}), \mathrm{M} 2 \times \mathrm{M} 1(0.27$ $\mathrm{g} / 100 \mathrm{~g})$ and M2 $\times \mathrm{S} 2(0.27 \mathrm{~g} / 100 \mathrm{~g})$ were the best hybrids for methionine. Kernel methionine results showed that $d z r l$ containing lines were successful at producing high methionine hybrids. Darrigues et al. (2005) reported a methionine concentration of $0.210 \mathrm{~g} / 100 \mathrm{~g}$, in the $d z r l$ inbred B101. Huffman et al. (2016) found this value to be $0.179 \mathrm{~g} / 100 \mathrm{~g}$ in hybrids in diallel crosses in which some parents contained $d z r l$. Although the findings were similar, relatively higher results were obtained from our study. A microbial method was used to determine the amount of methionine in Darrigues et al (2005) and Huffman et al. (2016). In our study, a high resolution chromatographic (LC-MS / MS) method was used. Differences in the the methods used may be partially responsible for the observed differences among studies.

LQI values ranged from 3.9 to $2.6 \%$ and the best hybrid combinations were M3 × K1 $(3.9 \%), \mathrm{M} 2 \times \mathrm{S} 1(3.8$ $\%)$ and $\mathrm{K} 1 \times \mathrm{M} 1(3.7 \%)$ hybrids. MQI values varied from $1.8 \%(\mathrm{~K} 1 \times \mathrm{M} 2)$ to $2.7 \%(\mathrm{M} 2 \times \mathrm{S} 1)$. The overall experiment average was $2.3 \%$ and the most successful hybrids were $\mathrm{M} 2 \times \mathrm{S} 1(2.7 \%)$ and $\mathrm{M} 3 \times \mathrm{S} 1(2.6 \%)$ genotypes, respectively. 
Table 6. Means of traits of the 56 hybrids obtained from an $8 \times 8$ full diallel mating design and commercial checks generated from two years and two sites

\begin{tabular}{|c|c|c|c|c|c|c|c|c|}
\hline Hybrids & $\begin{array}{l}\text { Yield } \\
\left(t_{\text { ha }}^{-1}\right)\end{array}$ & $\begin{array}{l}\text { Protein } \\
(\%)\end{array}$ & $\begin{array}{l}\text { Lysine } \\
\text { (g/100g) }\end{array}$ & $\begin{array}{l}\text { Methionine } \\
\text { (g/100g) }\end{array}$ & $\begin{array}{l}\text { KQI } \\
(\%)\end{array}$ & $\begin{array}{l}\text { MQI } \\
(\%)\end{array}$ & $\begin{array}{l}\text { Lysine yield } \\
\left(\mathrm{kg} \mathrm{ha}^{-1}\right)\end{array}$ & $\begin{array}{l}\text { Methionine } \\
\text { yield } \\
\left(\mathrm{kg} \mathrm{ha}^{-1}\right)\end{array}$ \\
\hline $\mathrm{K} 1 \times \mathrm{K} 2$ & 11.5 & 10.0 & 0.37 & 0.19 & 3.6 & 1.9 & 42.2 & 22.0 \\
\hline $\mathrm{K} 1 \times \mathrm{M} 1$ & 10.7 & 10.9 & 0.40 & 0.24 & 3.7 & 2.3 & 42.3 & 26.0 \\
\hline $\mathrm{K} 1 \times \mathrm{M} 2$ & 12.4 & 10.6 & 0.28 & 0.19 & 2.6 & 1.8 & 34.4 & 23.0 \\
\hline $\mathrm{K} 1 \times \mathrm{M} 3$ & 11.0 & 9.7 & 0.29 & 0.22 & 3.1 & 2.3 & 31.7 & 24.3 \\
\hline $\mathrm{K} 1 \times \mathrm{A} 1$ & 12.8 & 9.4 & 0.29 & 0.22 & 3.1 & 2.4 & 37.1 & 27.9 \\
\hline $\mathrm{K} 1 \times \mathrm{S} 1$ & 13.8 & 9.6 & 0.30 & 0.19 & 3.2 & 2.0 & 41.6 & 26.6 \\
\hline $\mathrm{K} 1 \times \mathrm{S} 2$ & 12.0 & 10.3 & 0.35 & 0.23 & 3.5 & 2.3 & 41.7 & 27.3 \\
\hline $\mathrm{K} 2 \times \mathrm{K} 1$ & 10.3 & 10.0 & 0.36 & 0.21 & 3.6 & 2.1 & 37.5 & 21.7 \\
\hline $\mathrm{K} 2 \times \mathrm{M} 1$ & 10.0 & 11.1 & 0.37 & 0.23 & 3.2 & 2.0 & 36.4 & 22.8 \\
\hline $\mathrm{K} 2 \times \mathrm{M} 2$ & 12.1 & 11.1 & 0.33 & 0.22 & 2.9 & 1.9 & 39.7 & 25.7 \\
\hline $\mathrm{K} 2 \times \mathrm{M} 3$ & 12.0 & 11.5 & 0.33 & 0.21 & 2.9 & 1.8 & 39.7 & 25.5 \\
\hline $\mathrm{K} 2 \times \mathrm{A} 1$ & 12.5 & 10.5 & 0.30 & 0.22 & 2.9 & 2.1 & 37.4 & 26.9 \\
\hline $\mathrm{K} 2 \times \mathrm{S} 1$ & 13.6 & 10.1 & 0.32 & 0.21 & 3.2 & 2.1 & 43.8 & 28.8 \\
\hline $\mathrm{K} 1 \times \mathrm{S} 2$ & 11.9 & 9.9 & 0.33 & 0.23 & 3.3 & 2.3 & 39.1 & 26.9 \\
\hline $\mathrm{M} 1 \times \mathrm{K} 1$ & 12.4 & 11.6 & 0.37 & 0.24 & 3.1 & 2.1 & 45.6 & 30.3 \\
\hline $\mathrm{M} 1 \times \mathrm{K} 2$ & 10.6 & 11.0 & 0.37 & 0.24 & 3.3 & 2.2 & 39.7 & 25.8 \\
\hline $\mathrm{M} 1 \times \mathrm{M} 2$ & 9.3 & 11.4 & 0.35 & 0.27 & 3.0 & 2.4 & 32.1 & 25.0 \\
\hline $\mathrm{M} 1 \times \mathrm{M} 3$ & 10.5 & 11.4 & 0.36 & 0.26 & 3.1 & 2.2 & 37.4 & 27.5 \\
\hline $\mathrm{M} 1 \times \mathrm{A} 1$ & 10.8 & 11.6 & 0.34 & 0.24 & 2.9 & 2.1 & 36.5 & 26.2 \\
\hline $\mathrm{M} 1 \times \mathrm{S} 1$ & 11.9 & 10.3 & 0.34 & 0.25 & 3.2 & 2.4 & 40.3 & 29.6 \\
\hline $\mathrm{M} 1 \times \mathrm{S} 2$ & 11.0 & 10.8 & 0.30 & 0.26 & 2.8 & 2.4 & 33.8 & 28.6 \\
\hline $\mathrm{M} 2 \times \mathrm{K} 1$ & 12.8 & 10.4 & 0.35 & 0.26 & 3.4 & 2.5 & 45.1 & 33.3 \\
\hline $\mathrm{M} 2 \times \mathrm{K} 2$ & 11.4 & 11.5 & 0.35 & 0.25 & 3.0 & 2.1 & 40.1 & 29.1 \\
\hline $\mathrm{M} 2 \times \mathrm{M} 1$ & 9.4 & 12.1 & 0.37 & 0.27 & 3.0 & 2.2 & 34.5 & 25.3 \\
\hline $\mathrm{M} 2 \times \mathrm{M} 3$ & 12.6 & 11.5 & 0.38 & 0.29 & 3.3 & 2.5 & 48.3 & 36.3 \\
\hline $\mathrm{M} 2 \times \mathrm{A} 1$ & 14.6 & 10.4 & 0.38 & 0.26 & 3.6 & 2.5 & 55.1 & 38.0 \\
\hline $\mathrm{M} 2 \times \mathrm{S} 1$ & 15.5 & 10.0 & 0.38 & 0.28 & 3.8 & 2.7 & 58.6 & 42.5 \\
\hline $\mathrm{M} 2 \times \mathrm{S} 2$ & 13.2 & 10.5 & 0.33 & 0.27 & 3.1 & 2.6 & 43.1 & 36.2 \\
\hline $\mathrm{M} 3 \times \mathrm{K} 1$ & 12.0 & 9.8 & 0.38 & 0.23 & 3.9 & 2.4 & 45.7 & 27.4 \\
\hline $\mathrm{M} 3 \times \mathrm{K} 2$ & 13.6 & 10.4 & 0.38 & 0.21 & 3.6 & 2.0 & 51.1 & 28.2 \\
\hline $\mathrm{M} 3 \times \mathrm{M} 1$ & 11.3 & 11.3 & 0.34 & 0.23 & 3.0 & 2.1 & 38.2 & 26.3 \\
\hline $\mathrm{M} 3 \times \mathrm{M} 2$ & 11.8 & 11.1 & 0.37 & 0.24 & 3.3 & 2.1 & 43.9 & 28.0 \\
\hline $\mathrm{M} 3 \times \mathrm{A} 1$ & 14.5 & 11.0 & 0.37 & 0.25 & 3.5 & 2.4 & 54.3 & 36.8 \\
\hline $\mathrm{M} 3 \times \mathrm{S} 1$ & 13.5 & 9.7 & 0.35 & 0.25 & 3.6 & 2.6 & 46.7 & 33.4 \\
\hline $\mathrm{M} 3 \times \mathrm{S} 2$ & 12.0 & 10.0 & 0.35 & 0.25 & 3.5 & 2.5 & 41.4 & 29.4 \\
\hline $\mathrm{A} 1 \times \mathrm{K} 1$ & 12.8 & 9.7 & 0.30 & 0.19 & 3.2 & 2.1 & 38.4 & 24.7 \\
\hline $\mathrm{A} 1 \times \mathrm{K} 2$ & 13.9 & 10.1 & 0.36 & 0.22 & 3.6 & 2.2 & 50.6 & 30.8 \\
\hline $\mathrm{A} 1 \times \mathrm{M} 1$ & 10.7 & 11.1 & 0.36 & 0.25 & 3.2 & 2.2 & 38.3 & 27.1 \\
\hline $\mathrm{A} 1 \times \mathrm{M} 2$ & 13.0 & 10.9 & 0.36 & 0.24 & 3.3 & 2.2 & 47.3 & 32.0 \\
\hline $\mathrm{A} 1 \times \mathrm{M} 3$ & 13.8 & 11.0 & 0.34 & 0.21 & 3.1 & 1.9 & 46.2 & 29.3 \\
\hline $\mathrm{A} 1 \times \mathrm{S} 1$ & 16.1 & 9.6 & 0.30 & 0.20 & 3.3 & 2.2 & 47.6 & 32.4 \\
\hline $\mathrm{A} 1 \times \mathrm{S} 2$ & 13.6 & 9.5 & 0.33 & 0.22 & 3.5 & 2.4 & 44.4 & 29.6 \\
\hline $\mathrm{S} 1 \times \mathrm{K} 1$ & 14.5 & 9.4 & 0.32 & 0.22 & 3.5 & 2.4 & 47.0 & 32.3 \\
\hline $\mathrm{S} 1 \times \mathrm{K} 2$ & 14.4 & 10.1 & 0.35 & 0.24 & 3.6 & 2.4 & 49.6 & 33.9 \\
\hline $\mathrm{S} 1 \times \mathrm{M} 1$ & 11.5 & 10.3 & 0.30 & 0.21 & 3.0 & 2.1 & 34.4 & 24.5 \\
\hline $\mathrm{S} 1 \times \mathrm{M} 2$ & 13.6 & 10.3 & 0.29 & 0.24 & 2.9 & 2.3 & 39.9 & 32.5 \\
\hline $\mathrm{S} 1 \times \mathrm{M} 3$ & 13.6 & 10.2 & 0.29 & 0.24 & 2.9 & 2.4 & 39.0 & 33.1 \\
\hline $\mathrm{S} 1 \times \mathrm{A} 1$ & 13.9 & 9.6 & 0.28 & 0.21 & 3.0 & 2.2 & 37.4 & 29.3 \\
\hline $\mathrm{S} 1 \times \mathrm{S} 2$ & 13.6 & 9.5 & 0.29 & 0.22 & 3.1 & 2.4 & 38.9 & 30.6 \\
\hline $\mathrm{S} 2 \times \mathrm{K} 1$ & 12.2 & 9.6 & 0.32 & 0.23 & 3.5 & 2.4 & 39.0 & 27.8 \\
\hline $\mathrm{S} 2 \times \mathrm{K} 2$ & 12.9 & 9.9 & 0.34 & 0.22 & 3.4 & 2.2 & 43.6 & 28.1 \\
\hline $\mathrm{S} 2 \times \mathrm{M} 1$ & 11.6 & 10.9 & 0.31 & 0.24 & 2.9 & 2.2 & 35.9 & 28.4 \\
\hline $\mathrm{S} 2 \times \mathrm{M} 2$ & 11.8 & 10.1 & 0.32 & 0.25 & 3.2 & 2.5 & 38.0 & 29.6 \\
\hline $\mathrm{S} 2 \times \mathrm{M} 3$ & 12.6 & 10.7 & 0.32 & 0.24 & 3.1 & 2.3 & 40.5 & 31.0 \\
\hline $\mathrm{S} 2 \times \mathrm{A} 1$ & 13.6 & 9.4 & 0.26 & 0.21 & 2.8 & 2.3 & 34.8 & 28.7 \\
\hline $\mathrm{S} 2 \times \mathrm{S} 1$ & 14.1 & 9.5 & 0.28 & 0.21 & 3.0 & 2.2 & 38.9 & 29.5 \\
\hline P31G98 & 14.1 & 9.5 & 0.29 & 0.22 & 3.2 & 2.4 & 41.6 & 30.9 \\
\hline DKC6589 & 15.3 & 9.6 & 0.28 & 0.21 & 3.0 & 2.2 & 43.5 & 31.7 \\
\hline Mean of experiment & 12.6 & 10.4 & 0.33 & 0.23 & 3.2 & 2.3 & 41.6 & 29.1 \\
\hline Mean of checks & 14.7 & 9.5 & 0.29 & 0.21 & 3.1 & 2.3 & 42.5 & 31.3 \\
\hline Mean of crosses & 12.5 & 10.4 & 0.33 & 0.23 & 3.2 & 2.3 & 41.6 & 29.0 \\
\hline $\mathrm{CV}$ & 14.1 & 5.2 & 3.93 & 5.66 & 3.8 & 5.8 & 13.99 & 14.08 \\
\hline LSD & $1.43^{* *}$ & $0.43 * *$ & $0.0129 * *$ & $0.013^{* *}$ & $0.12 * *$ & $0.13 * *$ & $4.7^{* * *}$ & $3.3^{* *}$ \\
\hline
\end{tabular}

* Significant at the 0.05 probability level, $* *$ Significant at the 0.01 probability level, ${ }^{\text {ns }}$ not significant

Germplasm carrying opaque-2 and $d z r l$ has potential yield. While grain value is normally determined by the to increase grain lysine and methionine concentration. mass of grain produced per area of land, an alternative However, this germplasm may contribute to lower grain value calculation could be based on the amount of amino 
acid produced per area of land. Therefore, we calculated hybrid lysine and methionine yield $\left(\mathrm{kg} \mathrm{ha}^{-1}\right)$. Although cross and experiment lysine yield mean (41.6 $\mathrm{kg} \mathrm{ha}^{-1}$ ) were not signifcantly different than check means $(42.5 \mathrm{~kg}$ ha $\left.^{-1}\right), 8$ hybrids were sigificantly higher than the checks in this trait. Lysine yields ranged from 58.6 to $31.7 \mathrm{~kg} \mathrm{ha}^{-1}$. $\mathrm{M} 2 \times \mathrm{S} 1$ hybrid $\left(58.6 \mathrm{~kg} \mathrm{ha}^{-1}\right)$ had $27 \%$ more lysine yield than commercial high yielding normal hybrids. Methionine yield ranged from 42.5 to $22 \mathrm{~kg}$ ha- 1 . The best methionine yield hybrid, M2 $\times \mathrm{S} 1\left(42.5 \mathrm{~kg} \mathrm{ha}^{-1}\right)$, was higher than the check mean by $26 \%$ and 7 hybrids were signficantly higher than the checks. Interestingly, the best lysine yield hybrids were also the best methionine yield hybrids.

Combinations of major genes have been used extensively in the development of sweet corn (Boyer and Shannon, 1983) or in the development of maize with novel starches (Wang et al., 1993). This study contributed information on methionine and lysine genetics.

In conclusion, the results suggest that high grain yield can be achived in normal $\times$ normal or $d z r l \times$ normal endosperm crosses. In general, lower grain yields were obtained from crosses containing high amino acid inbreds. High lysine and methionine yields showed that combinations of opaque-2 and $d z r l$ might be useful in breeding programs with the goal of producing high yielding and high protein quality hybrids.

\section{ACKNOWLEDGMENTS}

This research was supported by The Scientific and Technological Research Council of Turkey (TUBITAK) (Project No: 115O394).

\section{LITERATURE CITED}

AOAC International. 2002. Crude Protein in Cereal Grains and Oilseeds, Official Methods of Analysis of AOAC International. AOAC International, Washington, DC.

Betran, F.J., A. Bockholt, F. Fojt, L. Rooney, R. Waniska. 2003a. Registration of parental lines: Registration of $T \times 802$. Crop Sci. 43 (5): 1891-1892.

Betran, F.J., A. Bockholt, F. Fojt, G. Odvody. 2003b. Registration of $\mathrm{T} \times 807$ maize line. Crop Sci. 43 (5):18921893.

Boyer, C.D. and J.C. Shannon. 1983. The use of endosperm genes for sweet corn improvement. In: Plant Breeding Reviews, ed, Janick J. Springer, Boston, MA

Carena, M.J. and N. Dong. 2017. The ND early QPM program: developing the next generation of healthier maize (Zea mays L.) products. Euphytica 213 (7):150.

Chan, P.T. and P. Matanjun. 2017. Chemical composition and physicochemical properties of tropical red seaweed, Gracilaria changii. Food Chem. 221: 302-310.

Darrigues, A., C. Buffard, K.R. Lamkey, M.P. Scott. 2005. Variability and genetic effects for tryptophan and methionine in commercial maize germplasm. Maydica. 50 (2):147-156.

Duraes, F.O.M., P.C. Magalhaes, A.C. Oliveira, M.X. Santos, E.E. Gomes, C.T. Guimares. 2002. Combining ability of tropical maize inbred lines under drought stress conditions, Crop Breed Appl Biotechnol. 2 (2):291-298.

Erdal, S. 2019. Determination of drought tolerance levels of maize inbred lines. Turkjans. 6 (2): 178-189.
Erdal, S., M. Pamukcu, A. Ozturk, K. Aydinsakir, S. Soylu. 2015. Combining abilities of grain yield and yield related traits in relation to drought tolerance in temperate maize breeding. Turk J Field Crops. 20 (2): 203-212.

Faountoulakis, M. and H.W. Lahm. 1998. Hydrolysis and amino acid composition analysis of proteins. J Chromatogr A. 826 (2): 109-134

Fisher, R.A. 1935. The Design of Experiments. 7th ed. London: Oliver and Boyd; New York: Hafner.

Griffing, B. 1956. Concept of general and specific combining ability in relation to diallel crossing systems. Aust J Biol Sci. 9 (4):463-493.

Hallauer, A.R. and M.J. Carena. 2009. Maize breeding. In: Handbook of Plant Breeding: Cereals, ed, Carena M.J. Springer, New York, pp 3-98.

Harms, R.H. and G.B. Russell. 1998. Layer performance when returned to a practical diet after receiving an amino aciddeficient diet. J Appl Poultry Res. 7 (2):175-179.

Huffman, R.D., J.W. Edwards, L.M. Pollak, M.P. Scott. 2016. Interaction of genetic mechanisms regulating methionine concentration in maize grain. Crop Sci. 56 (5):1-11.

Krivanek, A., H. Groote, N. Gunaratna, A. Diallo, D. Freisen. 2007. Breeding and disseminating quality protein maize for Africa. Afr J Biotechnol. 6 (4): 312-324

Mbuya, K., K.K. Nkongolo, A. Kalonji-Mbuyi. 2011. Nutritional analysis of quality protein maize varieties selected for agronomic characteristics in a breeding program. Int J Plant Breed Genet. 5 (4): 317-327.

Mertz, E.T., L.S. Bates, O.E. Nelson. 1964. Mutant that changes protein composition and increases lysine content of maize endosperm. Science 145 (3629):279-280.

Nas, L., M. Lima, R. Vencovsky, P.B. Gallo. 2000. Combining ability of maize inbreed lines evaluation in the three environment in Brazil. Scientia Agricola 57 (1): 129-134.

Olsen, M.S,, T.L. Krone, R.L. Phillips. 2003. BSSS53 as a donor source for increased whole-kernel methionine in maize: Selection and evaluation of high-methionine inbreds and hybrids. Crop Sci. 43 (5):1634-1642.

Phillips, R.L., J. Suresh, M. Olsen, T. Krone. 2008. Registration of high-methionin versions of maize inbreds A 632, B73 and Mo17. J Plant Reg. 2(3):243-245.

Phillips, R.L. and B.A. McClure. 1985. Elevated protein-bound methionine in seeds of a maize line resistant to lysine plus threonine. Cereal Chem. 62 (3):213-218.

Ravindran, V. 2012. Poultry Feed Availability and Nutrition in Developing Countries. Food and Agriculture Organization of the United Nations, Poultry Development Review 1-4.

Rodriguez, F., G. Alvarado, A. Pacheco, J. Crossa, J. Burgueño. 2015. AGD-R (Analysis of Genetic Designs with R for Windows) Version 2.0. http://hdl.handle.net/11529/10202 International Maize and Wheat Improvement Center (Accessed September 15, 2017).

Saki, A.A., H.R. Naseri, M.M. Tabatabaei, P. Zamani, M. Haghight. 2012. Estimates of methionine and sulfur amino acid requirements for laying hens using different models. Braz J Poultry Sci.14 (3):159-232.

Schutte, J.B. and J. De Jong. 1999. Ideal amino acid profile for poultry. In: Feed Manufactoring in the Mediterranean Region. Recent Advances in Research and Technology, ed, Brufao, J. and Tacon, A. Zaragoza: CIHEAM - Options Mediterraneennes. 259-263

Scott, MP., J.M. Peterson, A.R. Hallauer. 2009. Evaluation of combining ability of quality protein maize derived from U.S. public inbred lines. Maydica 54 (4): 449-456

Scott, M.P., S. Bhatnagar and J. Betran. 2004. Tryptophan and methionine levels in quality protein maize breeding germplasm. Maydica 49 (2004):303-311. 
Scott, P.M., A. Darrigues, S.S. Timothy, K. Lamkey. 2008. Recurrent selection to alter grain methionine concentration and improve nutritional value of maize. Crop Sci. 48 (5):1705-1713.

Steel, R.G.D. and J.H. Torrie. 1980. Principles and procedures of statistics. A biometrical approach, 2nd Edition, McGraw-Hill Book Company, New York.

TTSMM 2018. Maize. Technical instructions for agricultural trials in maize https://www.tarimorman.gov.tr/BUGEM/TTSM/Belgeler/Te scil/Teknik\%20Talimatlar/S\%C4\%B1cak\%20\%C4\%B0klim $\% 20 \mathrm{Tah} \% \mathrm{C} 4 \% \mathrm{~B} 111 \mathrm{ar} \% \mathrm{C} 4 \% \mathrm{~B} 1 / \mathrm{MISIR}$ TEKNIK_TALIMA TI.pdf (Accessed February 15, 2020, in Turkish).
Vasal, S.K., G. Srinivasan, S. Pandey, C.F. Gonzalez, J. Crossa, D.L. Beck. 1993. Heterosis and combining ability of CIMMYT's quality protein maize germplasm I: Lowland tropical. Crop Sci. 33 (1):46-51.

Vivek, B.S., A.F. Krivanek, N. Palacios, S.T. Afriyie, A.O. Diallo. 2008. Breeding Quality Protein Maize (QPM): Protocols for Developing QPM Cultivars. Mexico, D.F: CIMMYT.

Wang, Y.J., P. White, L. Pollak and J. Jane. 1993. Characterization of starch structures of 17 maize endosperm mutant genotypes with Oh43 inbred line background. Cereal Chem. 70 (2): 171-178. 